Article

\title{
Phytochemical Analysis and Biological Investigation of Nepeta juncea Benth. Different Extracts
}

\author{
Majid Sharifi-Rad ${ }^{1, *}{ }^{\text {, Francesco Epifano }}{ }^{2}$ (D) Serena Fiorito ${ }^{2}$ and José M. Álvarez-Suarez ${ }^{3,4, *(\mathbb{D})}$ \\ 1 Department of Range and Watershed Management, Faculty of Water and Soil, University of Zabol, \\ Zabol 98613-35856, Iran \\ 2 Dipartimento di Farmacia, Università “Gabriele d'Annunzio" Chieti-Pescara, Via dei Vestini 31, \\ 66100 Chieti Scalo (CH), Italy; fepifano@unich.it (F.E.); serena.fiorito@unich.it (S.F.) \\ 3 King Fahd Medical Research Center, King Abdulaziz University, Jeddah 21589, Saudi Arabia \\ 4 Grupo de Investigación en Biotecnología Aplicada a Biomedicina (BIOMED). Universidad de Las Américas, \\ Quito 170125, Ecuador \\ * Correspondence: Majid.sharifirad@gmail.com (M.S.-R.); jose.alvarez@udla.edu.ec (J.M.Á.-S.); \\ Tel.: +98-17322312294 (M.S.-R.); +593-2-398-1000 (ext. 7500) (J.M.Á.-S.)
}

Received: 14 April 2020; Accepted: 12 May 2020; Published: 19 May 2020

check for updates

\begin{abstract}
This study was carried out to screen the amount and the classes of secondary metabolites and to evaluate the antioxidant, cytotoxic, antifungal, and antibacterial activities of the methanolic, ethanolic, and water extracts of the roots, leaves, and flowers of Nepeta juncea Benth. The results show that the highest total phenol $(69.54 \pm 0.31 \mathrm{mg}$ gallic acid equivalents (GAE)/g dry weight), total flavonoid (41.37 $\pm 0.17 \mathrm{mg}$ quercetin equivalents $(\mathrm{QE}) / \mathrm{g}$ dry weight), anthocyanin $(6.52 \pm 0.21 \mathrm{mg}$ cyanidin/100 g dry weight), and tannin (47.36 $\pm 0.33 \mathrm{mg}$ catechin/g dry weight) concentrations were recorded in the methanolic extract of the leaves of $N$. juncea. The gas chromatography-mass spectrometry (GC-MS) analysis of the extracts showed that 1,8-cineole, $4 \mathrm{a} \alpha-7 \alpha$-7a $\alpha$-nepetalactone, $\beta$-pinene, terpinen-4-ol, and $\alpha$-terpineol were the major compounds, respectively. The best 2 , 2-diphenyl-1-picrylhydrazyl (DPPH) radical scavenging and ferric-reducing antioxidant, cytotoxic, antifungal, and antibacterial activities were observed for the methanolic extract of the leaves. For the two latter activities, the best activity was revealed on Staphylococcus aureus, Bacillus cereus, and Candida albicans. The minimum inhibitory concentration (MIC) values for the antimicrobial of the methanolic extract from the leaves were in the range of $25-100 \mu \mathrm{g} / \mathrm{mL}$, whereas the minimum bactericidal concentration (MBC) values were in the range of 50-200 $\mathrm{gg} / \mathrm{mL}$. The results reported herein show that, for the first time in the literature, N. juncea is a remarkable source of antioxidant, antifungal, and antibacterial compounds.
\end{abstract}

Keywords: biological activities; bioactive compounds; human cancer cells; Nepeta juncea Benth

\section{Introduction}

Plants have represented an important source of bioactive compounds (e.g., phenolics, terpenoids, aromatic components, essential oils, sterols, alkaloids, polysaccharides, tannins, and anthocyanin) for centuries [1,2]. Natural compounds play a significant role in drug discovery and in the development of novel therapeutic entities [3]. In recent decades, much attention has been paid to investigating the antioxidant and antibacterial activities of medicinal plants [4-6]. It has been proven that the antioxidant properties of medicinal plant products are mainly attributed to the above-mentioned phytochemicals [7]. These natural antioxidants prevent the destructive effects induced by oxidative stress of reactive oxygen species (ROS) [8,9], which are well known to be implicated in aging [10] and many acute and chronic diseases such as diabetes [11], cancer [12], and neurodegenerative disorders [13]. On the other hand, 
bacterial resistance to synthetic and semi-synthetic antibiotics is a rapidly increasing problem [14]. In addition, these antibiotics cause different adverse drug reactions such as immuno-suppression and hypersensitivity [15]. To overcome this problem, it is vital to find new antimicrobial agents that are not only able to suppress bacterial infections but are also able to have a long-lasting effect by boosting immune functions [16,17]. Likewise, multidrug drug resistance of cancer cells can lead to chemotherapy failure during the course of cancer treatment [18]. Thus, the use of phytotherapeutics is a promising anticancer method with fewer side effects than conventional medicines and is also an interesting strategy to prevent contaminations and infections in medicine and food products [19].

Candidiasis is the most common fungal infection. Candida glabrata and Candida albicans are two species that are usually implicated in the clinical picture. The candidiasis spectrum is vast, from mild symptoms such as the colonization of mucosal tissue to systemic pictures, with the invasion of various organs [20]. These yeasts are common microbiota and can become pathogenic in cases such as acquired or congenital immunodeficiency and immunosuppression due to severe stress [21]. Many extract types have been extensively studied in search of alternative therapies to combat these infections, e.g., Mentha longifolia (L.) Huds. [22], Malva sylvestris L. and Psidium guajava L. [23], and Satureja intermedia C.A.Mey [19].

The Nepeta genus is widely used in traditional medicine and is commonly applied for its anti-Alzheimer, anti-seizure, anti-nociceptive, memory enhancing, neuroprotective, antidepressant, and anti-infective effects in Iranian folk medicine [24]. It belongs to the Lamiaceae family, subfamily Nepetoideae, tribe Mentheae. Nepeta species are widely distributed across North America, Europe, Africa, and Asia; about 76 species of the genus Nepeta are found in Iran and Turkey, 58 in Pakistan, and 35 species in Western Himalaya [24]. Many biological activities have been reported for Nepeta spp., such as antioxidant, antibacterial, antifungal, anti-inflammatory, insecticidal, analgesic, and antidepressant activities, among others [24,25]. According to the phytochemical composition, this genus can be considered as two groups: the first group contains a high percentage of nepetalactone and its isomers, and, in the second group, 1,8-cineole and/or linalool are the main compounds [26]. Nepetalactones are the main compound (50-95\%) in N. cataria, N. caesarea, N. racemosa, N. argolica, N. sibirica, N. elliptica, N. x faasenii, N. rtanjensis, N. meyeri, N. nepetella, N. saccharata, N. coerulea, and N. parnassica. A medium percentage of the nepetalactones (14-50\%) is reported for N. betonicifolia, N. grandiflora, N. spruneri, N. persica and N. crispa. Finally, there are species that have minor percentage of the nepetalactones $(0.5-7 \%)$ such as $N$. pogonosperma, N. leucolaena, and N. sulfuriflora. In these species, 1,8-cineole is the main compound [24]. N. cataria is one of the most investigated species of this genus, the results of which confirm its traditional applications [24]. Recent studies have reported promising activities for the Nepeta binaludensis Jamzad and Nepeta satureioides Boiss extracts, e.g., inhibition of melanogenesis and antioxidant activity $[24,27]$. The main purpose of this study was to investigate the phytochemical composition and to assess the antioxidant, cytotoxic, antifungal, and antibacterial activities of the methanolic, ethanolic, and water extracts of the roots, leaves, and flowers of N. juncea Benth. To the best of our knowledge, there are no systematic studies on the in vitro antioxidant, cytotoxic, antifungal, and antibacterial activities of N. juncea Benth.

\section{Results and Discussion}

\subsection{Total Phenol Concentration}

The results of the total phenolic content determination of the $N$. juncea extracts are shown in Table 1. In all of the extracts, the total phenolic content was higher in the leaves extracts than in those from the roots and flowers. The highest content of total phenol was measured in the methanolic extract for each part of $N$. juncea, followed by the ethanol and water extracts, respectively. The methanolic extract of the leaves had the highest value of total phenol content $(69.54 \pm 0.31 \mathrm{mg}$ gallic acid equivalents $(\mathrm{GAE}) / \mathrm{g}$ dry weight), and the lowest total phenolic content (13.46 $\pm 0.26 \mathrm{mg} \mathrm{GAE} / \mathrm{g}$ dry weight) was observed in the water extract of the roots. The variation in the total phenolic content in the different extracts is 
related to the different solubility of the phenolic compounds; this change in solubility may be driven by the polarity of the solvent [28]. This is in line with the results of previous literature showing how methanol behaves as a better extraction solvent for phenolic compounds [29,30].

Table 1. The total phenols, total flavonoids, anthocyanin, and tannin concentrations in the different extracts of Nepeta juncea.

\begin{tabular}{cccccc}
\hline \multirow{2}{*}{ Solvent } & Plant Part & $\begin{array}{c}\text { Total Phenols } \\
\text { (mg GAE/g } \\
\text { Dry Weight) }\end{array}$ & $\begin{array}{c}\text { Total Flavonoids } \\
\text { (mg QE/g Dry } \\
\text { Weight) }\end{array}$ & $\begin{array}{c}\text { Anthocyanin }(\mathbf{m g} \\
\text { Cyanidin/100 g } \\
\text { Dry Weight) }\end{array}$ & $\begin{array}{c}\text { Tannin (mg } \\
\text { Catechin/g Dry } \\
\text { Weight) }\end{array}$ \\
\hline \multirow{3}{*}{ Methanol } & Leaves & $69.54 \pm 0.31^{\mathrm{a}}$ & $41.37 \pm 0.17^{\mathrm{a}}$ & $6.52 \pm 0.21^{\mathrm{a}}$ & $47.36 \pm 0.33^{\mathrm{a}}$ \\
\cline { 2 - 6 } & Flowers & $45.61 \pm 0.14^{\mathrm{c}}$ & $26.42 \pm 0.31^{\mathrm{c}}$ & $4.35 \pm 0.34^{\mathrm{c}}$ & $32.16 \pm 0.21^{\mathrm{c}}$ \\
\cline { 2 - 6 } & Roots & $21.33 \pm 0.46^{\mathrm{g}}$ & $9.62 \pm 0.15^{\mathrm{g}}$ & $2.89 \pm 0.42^{\mathrm{f}}$ & $23.15 \pm 0.15^{\mathrm{f}}$ \\
\hline \multirow{3}{*}{ Ethanol } & Leaves & $52.36 \pm 0.27^{\mathrm{b}}$ & $34.23 \pm 0.29^{\mathrm{b}}$ & $3.42 \pm 0.43^{\mathrm{d}}$ & $28.14 \pm 0.35^{\mathrm{d}}$ \\
\cline { 2 - 6 } & Flowers & $30.22 \pm 0.14^{\mathrm{e}}$ & $19.81 \pm 0.53^{\mathrm{e}}$ & $2.45 \pm 0.28^{\mathrm{g}}$ & $19.31 \pm 0.14^{\mathrm{g}}$ \\
\cline { 2 - 6 } & Roots & $18.12 \pm 0.28^{\mathrm{h}}$ & $7.16 \pm 0.26^{\mathrm{h}}$ & $1.51 \pm 0.14^{\mathrm{i}}$ & $10.21 \pm 0.26^{\mathrm{i}}$ \\
\hline \multirow{3}{*}{ Water } & Leaves & $33.17 \pm 0.34^{\mathrm{d}}$ & $23.25 \pm 0.49^{\mathrm{d}}$ & $4.63 \pm 0.27^{\mathrm{b}}$ & $36.21 \pm 0.24^{\mathrm{b}}$ \\
\cline { 2 - 6 } & Flowers & $24.71 \pm 0.12^{\mathrm{f}}$ & $14.32 \pm 0.13^{\mathrm{f}}$ & $3.11 \pm 0.18^{\mathrm{e}}$ & $24.17 \pm 0.16^{\mathrm{e}}$ \\
\cline { 2 - 6 } & Roots & $13.46 \pm 0.26^{\mathrm{i}}$ & $5.23 \pm 0.35^{\mathrm{i}}$ & $1.96 \pm 0.36^{\mathrm{h}}$ & $16.11 \pm 0.52^{\mathrm{h}}$ \\
\hline
\end{tabular}

The mean values within the columns that share different letters are significantly different, $p<0.05(n=3)$. GAE, gallic acid equivalents; $\mathrm{QE}$, quercetin equivalents.

\subsection{Total Flavonoid Concentration}

The results of the total flavonoid content determination of the $N$. juncea extracts are shown in Table 1. The methanolic extract of the leaves showed higher values of flavonoid content $(41.37 \pm 0.17 \mathrm{mg}$ quercetin equivalents $(\mathrm{QE}) / \mathrm{g}$ dry weight) than the other extracts under investigation. On the contrary, the flavonoid concentration of the water extract of the roots was the lowest $(5.23 \pm 0.35 \mathrm{mg} \mathrm{QE} / \mathrm{g}$ dry weight).

\subsection{Total Anthocyanin Concentration}

As shown in Table 1, the maximum total anthocyanin content $(6.52 \pm 0.21 \mathrm{mg}$ cyanidin/100 $\mathrm{g}$ dry weight) was observed in the methanolic extract of the leaves, and the minimum $(1.51 \pm 0.14 \mathrm{mg}$ cyanidin/100 g dry weight) was recorded in the ethanolic extract of the roots. Comparing the solvents, the anthocyanin concentration followed the order of methanol $>$ water $>$ ethanol, meaning that methanol is the best solvent for anthocyanin extraction from $N$. juncea. This result is in accordance with previous findings [31,32].

\subsection{Total Tannin Concentration}

The results of the total tannin content determination of the N. juncea extracts are shown in Table 1. Among the three extracts, the methanolic extract of the leaves showed the maximum tannin content $(47.36 \pm 0.33 \mathrm{mg}$ catechin/g dry weight), and the ethanolic extract of the roots showed the minimum tannin content $(10.21 \pm 0.26 \mathrm{mg}$ catechin/g dry weight). It is reported that the yields of extraction increase with the polarity of the solvent [33]; accordingly, maximum extraction yields are usually achieved using methanol or water as a solvent [34]. Comparing the different plant parts, the tannin content followed the order of leaves $>$ flowers $>$ roots for each solvent.

\subsection{Gas Chromatography-Mass Spectrometry Analysis}

The chemical composition of the $N$. juncea extracts is shown in Table 2. The main constituents were 1,8-Cineole, $4 \mathrm{a} \alpha-7 \alpha$-7a $\alpha$-Nepetalactone, $\beta$-Pinene, Terpinen-4-ol, and $\alpha$-Terpineol, respectively 
(Figure 1). Several reports have described the antioxidant and the antimicrobial activities of these compounds [35-38]. Shafaghat and Khodamali [37] analyzed the leaf oil of N. persica, in which $4 \mathrm{a} \beta, 7 \alpha, 7 \mathrm{a} \beta$-Nepetalactone (62.3\%), $4 \mathrm{a} \alpha, 7 \alpha, 7 \mathrm{a} \beta$-Nepetalactone $(28.3 \%)$, and $\beta$-ocimene (3.6\%) were the major components, followed by $\alpha$-pinene $(1.8 \%)$. The essential oils isolated from the different parts of N. sintenisii Bornm. (i.e., flower, leaf, stem, and root) were analyzed by GC and GC-MS. $4 \mathrm{a} \beta, 7 \alpha, 7 \mathrm{a} \beta$-Nepetalactone was characterized in the flower $(60.3 \%)$, leaf $(34.6 \%)$, stem $(64.2 \%)$, and root $(61.2 \%)$ as the main constituent, and the highest and lowest amounts of nepetalactone isomers were observed in the flower and root, respectively [39].

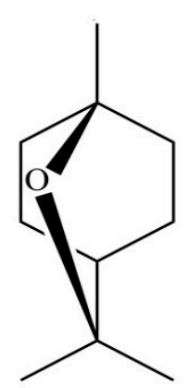

1,8-Cineole

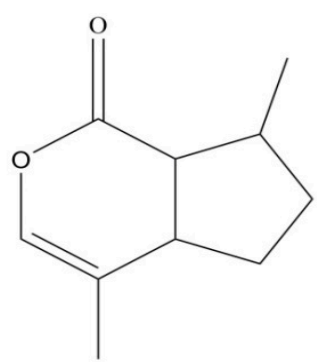

a $\alpha-7 \alpha-7 \mathrm{a} \alpha-$ Nepetalactone

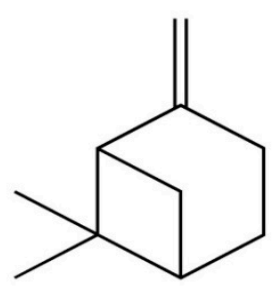

$\beta$-Pinene<smiles>CC1=CCC(O)(C(C)C)CC1</smiles>

Terpinen-4-ol<smiles>CC1=CCC(C(C)(C)O)CC1</smiles>

$\alpha$-Terpineol

Figure 1. Chemical structure of the major compounds of the Nepeta juncea extracts.

\subsection{Radical Scavenging Activity}

The free radical scavenging properties of the extracts were determined by the 2,2-diphenyl1-picrylhydrazyl (DPPH) assay (Figure 2). The methanolic extract of the leaves had the maximum and the water extract of the roots had the minimum antiradical activities. It was observed that the methanolic extract of $N$. juncea had the highest activity, followed by the ethanolic and water extracts, respectively. For each solvent, the antioxidant activity decreased according to the following order: leaves $>$ flowers $>$ roots. In this study, as in many other studies [40,41], a direct relationship between antioxidant activity and total phenolic and flavonoid content was observed. The results show that the $\mathrm{IC}_{50}(50 \%$ inhibitory concentration) of the different extracts varied between $1.19 \pm 0.03$ and $2.46 \pm 0.02 \mathrm{mg} / \mathrm{mL}$.

\subsection{Ferric Reducing Antioxidant Power (FRAP) Assay}

Figure 3 shows the antioxidant activity of the extracts using the FRAP assay. According to the results, the methanolic extract of the leaves was the most active extract in the FRAP assay, and the water extract of the roots showed the lowest antioxidant activity. In many studies, it has been reported that there is a direct correlation between the antioxidant activity and the content of phenolics, flavonoids, anthocyanin, and tannins of plant extracts [42-44]. According to the results, the highest value of phenolic, flavonoid, tannin, and anthocyanin contents was recorded in the methanolic extract of the leaves. 
Table 2. Chemical composition of the Nepeta juncea extracts.

\begin{tabular}{|c|c|c|c|c|c|c|c|c|c|c|c|}
\hline \multirow{2}{*}{ Compound } & \multirow{2}{*}{ RI } & \multirow{2}{*}{$\begin{array}{l}\text { Molecular } \\
\text { Formula }\end{array}$} & \multicolumn{3}{|c|}{ Methanolic Extract } & \multicolumn{3}{|c|}{ Ethanolic Extract } & \multicolumn{3}{|c|}{ Water Extract } \\
\hline & & & $\begin{array}{l}\text { Leaves } \\
(\%)\end{array}$ & $\begin{array}{c}\text { Flowers } \\
(\%)\end{array}$ & $\begin{array}{l}\text { Roots } \\
(\%)\end{array}$ & $\begin{array}{c}\text { Leaves } \\
(\%)\end{array}$ & $\begin{array}{c}\text { Flowers } \\
(\%)\end{array}$ & $\begin{array}{l}\text { Roots } \\
(\%)\end{array}$ & $\begin{array}{l}\text { Leaves } \\
(\%)\end{array}$ & $\begin{array}{c}\text { Flowers } \\
(\%)\end{array}$ & $\begin{array}{c}\text { Roots } \\
(\%)\end{array}$ \\
\hline$\alpha$-Thujene & 924 & $\mathrm{C}_{10} \mathrm{H}_{16}$ & 0.7 & 0.4 & 0.2 & 0.4 & 0.3 & 0.2 & 0.2 & 0.2 & 0.1 \\
\hline$\alpha$-Pinene & 935 & $\mathrm{C}_{10} \mathrm{H}_{16}$ & 1.8 & 0.9 & 0.3 & 1.2 & 0.7 & 0.1 & 0.7 & 0.3 & 0.1 \\
\hline Sabinene & 970 & $\mathrm{C}_{10} \mathrm{H}_{16}$ & 0.2 & - & - & 0.1 & - & - & - & - & - \\
\hline$\beta$-Pinene & 976 & $\mathrm{C}_{10} \mathrm{H}_{16}$ & 4.3 & 1.6 & 0.5 & 2.7 & 0.9 & 0.3 & 1.1 & 0.5 & 0.2 \\
\hline Myrcene & 984 & $\mathrm{C}_{10} \mathrm{H}_{16}$ & 0.1 & 0.1 & - & - & 0.1 & - & - & - & - \\
\hline$\alpha$-Terpinene & 1014 & $\mathrm{C}_{10} \mathrm{H}_{16}$ & 0.4 & 0.2 & 0.1 & 0.1 & 0.1 & 0.1 & - & 0.1 & 0.1 \\
\hline$p$-Cymene & 1019 & $\mathrm{C}_{10} \mathrm{H}_{14}$ & 0.5 & 0.2 & 0.1 & 0.2 & 0.1 & 0.1 & 0.1 & 0.1 & - \\
\hline 1,8-Cineole & 1032 & $\mathrm{C}_{10} \mathrm{H}_{18} \mathrm{O}$ & 41.6 & 20.2 & 4.1 & 24.3 & 15.4 & 2.2 & 11.2 & 8.7 & 1.4 \\
\hline$\gamma$-Terpinene & 1053 & $\mathrm{C}_{10} \mathrm{H}_{16}$ & 0.1 & - & - & - & - & - & - & - & - \\
\hline cis-Sabinene hydrate & 1058 & $\mathrm{C}_{10} \mathrm{H}_{18}$ & - & 0.1 & - & - & 0.1 & - & - & 0.1 & - \\
\hline Terpinolene & 1080 & $\mathrm{C}_{10} \mathrm{H}_{16}$ & 0.3 & 0.2 & 0.1 & 0.1 & 0.2 & 0.1 & 0.1 & 0.1 & 0.1 \\
\hline Linalool & 1085 & $\mathrm{C}_{10} \mathrm{H}_{18} \mathrm{O}$ & 0.8 & 0.5 & & 0.3 & 0.3 & & 0.1 & 0.2 & \\
\hline $\begin{array}{l}\text { trans-Sabinene } \\
\text { hydrate }\end{array}$ & 1088 & $\mathrm{C}_{10} \mathrm{H}_{18} \mathrm{O}$ & 0.3 & - & 0.1 & - & - & 0.1 & 0.1 & - & - \\
\hline trans-Pinocarveol & 1127 & $\mathrm{C}_{10} \mathrm{H}_{16} \mathrm{O}$ & - & 0.1 & - & - & 0.1 & - & - & - & - \\
\hline Sabinol & 1135 & $\mathrm{C}_{10} \mathrm{H}_{16} \mathrm{O}$ & 0.9 & 0.7 & 0.2 & 0.5 & 0.5 & 0.1 & 0.2 & 0.3 & 0.1 \\
\hline Pinocarvone & 1142 & $\mathrm{C}_{10} \mathrm{H}_{14} \mathrm{O}$ & 0.5 & 0.4 & 0.1 & 0.4 & - & 0.1 & 0.1 & - & 0.1 \\
\hline Isopulegol & 1145 & $\mathrm{C}_{10} \mathrm{H}_{18} \mathrm{O}$ & 0.6 & 0.7 & - & 0.5 & 0.5 & - & 0.3 & 0.2 & - \\
\hline Pinocamphone & 1161 & $\mathrm{C}_{10} \mathrm{H}_{16} \mathrm{O}$ & 0.3 & 0.3 & - & 0.1 & 0.2 & - & - & - & - \\
\hline Terpinen-4-ol & 1167 & $\mathrm{C}_{10} \mathrm{H}_{18} \mathrm{O}$ & 3.7 & 3.4 & 0.9 & 2.8 & 2.6 & 0.8 & 1.4 & 1.5 & 0.3 \\
\hline$\alpha$-Terpineol & 1177 & $\mathrm{C}_{10} \mathrm{H}_{18} \mathrm{O}$ & 2.3 & 1.9 & 0.8 & 1.3 & 0.9 & 0.5 & 0.8 & 0.6 & 0.2 \\
\hline Geraniol & 1225 & $\mathrm{C}_{10} \mathrm{H}_{18} \mathrm{O}$ & 0.6 & 0.5 & 0.2 & 0.4 & - & 0.1 & 0.1 & 0.1 & - \\
\hline
\end{tabular}


Table 2. Cont

\begin{tabular}{|c|c|c|c|c|c|c|c|c|c|c|c|}
\hline \multirow{2}{*}{ Compound } & \multirow{2}{*}{ RI } & \multirow{2}{*}{$\begin{array}{l}\text { Molecular } \\
\text { Formula }\end{array}$} & \multicolumn{3}{|c|}{ Methanolic Extract } & \multicolumn{3}{|c|}{ Ethanolic Extract } & \multicolumn{3}{|c|}{ Water Extract } \\
\hline & & & $\begin{array}{c}\text { Leaves } \\
(\%)\end{array}$ & $\begin{array}{c}\text { Flowers } \\
(\%)\end{array}$ & $\begin{array}{l}\text { Roots } \\
(\%)\end{array}$ & $\begin{array}{c}\text { Leaves } \\
(\%)\end{array}$ & $\begin{array}{c}\text { Flowers } \\
(\%)\end{array}$ & $\begin{array}{c}\text { Roots } \\
(\%)\end{array}$ & $\begin{array}{c}\text { Leaves } \\
(\%)\end{array}$ & $\begin{array}{c}\text { Flowers } \\
(\%)\end{array}$ & $\begin{array}{c}\text { Roots } \\
(\%)\end{array}$ \\
\hline Geranial & 1269 & $\mathrm{C}_{10} \mathrm{H}_{16} \mathrm{O}$ & 0.4 & - & 0.2 & 0.1 & - & 0.1 & 0.1 & - & 0.1 \\
\hline $4 \mathrm{a} \alpha-7 \alpha-7 \mathrm{a} \alpha$-Nepetalactone & 1340 & $\mathrm{C}_{10} \mathrm{H}_{14} \mathrm{O}_{2}$ & 16.2 & 18.4 & 9.3 & 10.1 & 12.4 & 7.6 & 4.3 & 5.3 & 3.7 \\
\hline $4 \mathrm{a} \alpha-7 \alpha-7 \mathrm{a} \beta-$ Nepetalactone & 1365 & $\mathrm{C}_{10} \mathrm{H}_{14} \mathrm{O}_{2}$ & 0.8 & 0.9 & 0.4 & 0.3 & 0.5 & 0.1 & 0.1 & 0.3 & 0.1 \\
\hline $4 a \beta-7 \alpha-7 a \beta-$ Nepetalactone & 1367 & $\mathrm{C}_{10} \mathrm{H}_{14} \mathrm{O}_{2}$ & 0.6 & 0.8 & 0.2 & 0.2 & 0.4 & 0.1 & 0.1 & 0.2 & - \\
\hline Geranyl acetate & 1384 & $\mathrm{C}_{12} \mathrm{H}_{20} \mathrm{O}_{2}$ & 0.1 & - & 0.1 & - & - & 0.1 & - & - & - \\
\hline$\beta$-Farnesene & 1449 & $\mathrm{C}_{15} \mathrm{H}_{24}$ & 0.1 & - & - & 0.1 & - & - & 0.1 & - & - \\
\hline Germacrene-d & 1483 & $\mathrm{C}_{15} \mathrm{H}_{24}$ & 0.3 & 0.1 & - & 0.2 & 0.1 & - & 0.1 & - & - \\
\hline cis- $\alpha$-Bisabolene & 1493 & $\mathrm{C}_{15} \mathrm{H}_{24}$ & - & 0.1 & - & - & - & - & - & - & - \\
\hline$\alpha$-Farnesene & 1497 & $\mathrm{C}_{15} \mathrm{H}_{24}$ & 0.2 & - & 0.2 & 0.1 & - & 0.1 & 0.1 & - & 0.1 \\
\hline Spathulenol & 1575 & $\mathrm{C}_{15} \mathrm{H}_{24} \mathrm{O}$ & 0.1 & 0.1 & - & - & - & - & - & 0.1 & - \\
\hline $\begin{array}{l}\text { Total identified } \\
\text { compounds } \%\end{array}$ & & & 78.8 & 52.8 & 18.1 & 46.5 & 36.4 & 12.9 & 21.4 & 18.9 & 6.7 \\
\hline
\end{tabular}




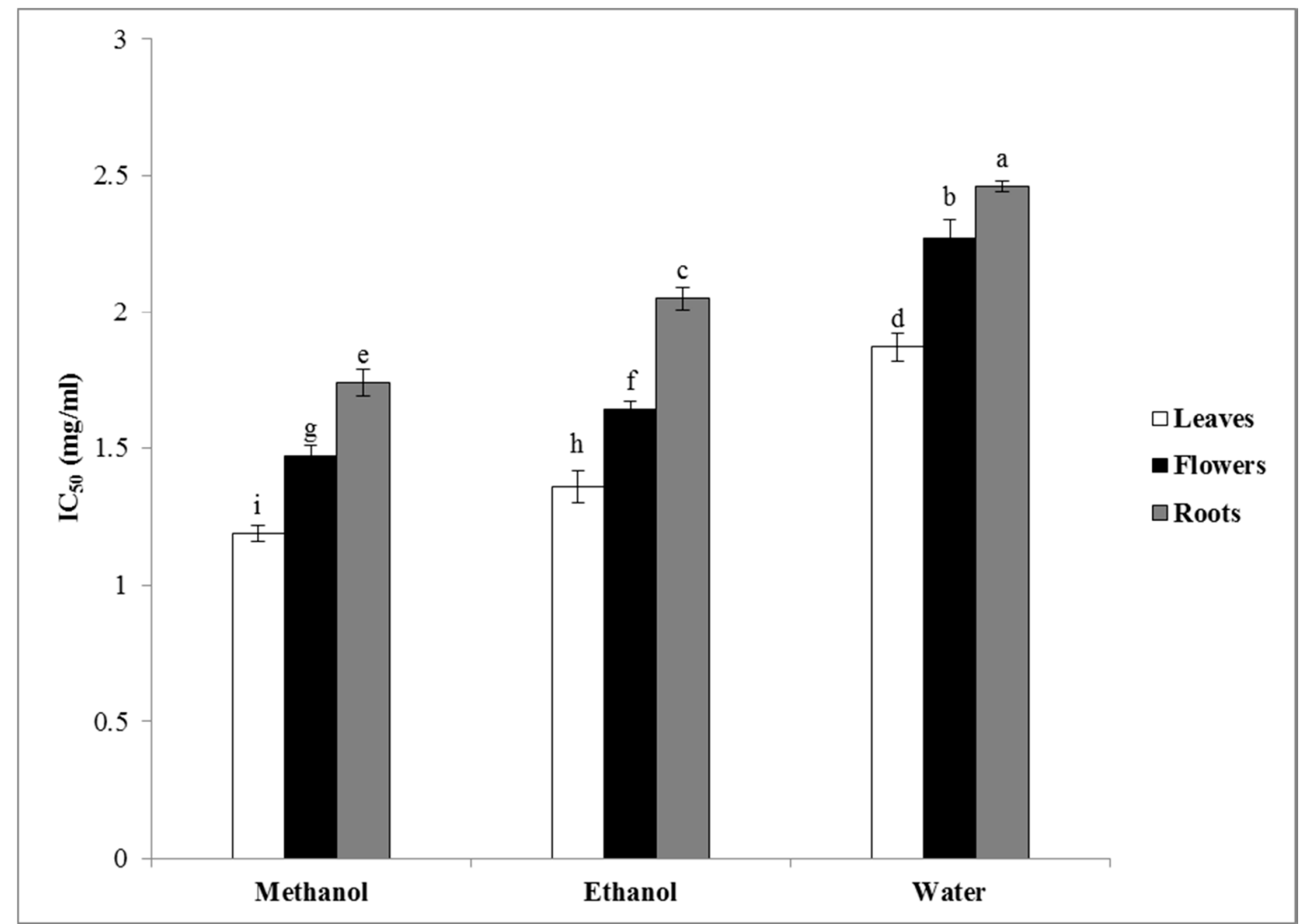

Figure 2. DPPH scavenging activity (expressed as $\mathrm{IC}_{50}$ (50\% inhibitory concentration)) of the different extracts of Nepeta juncea. Columns belonging to the same dataset and labeled with different letters are significantly different, $p<0.05(n=3)$.

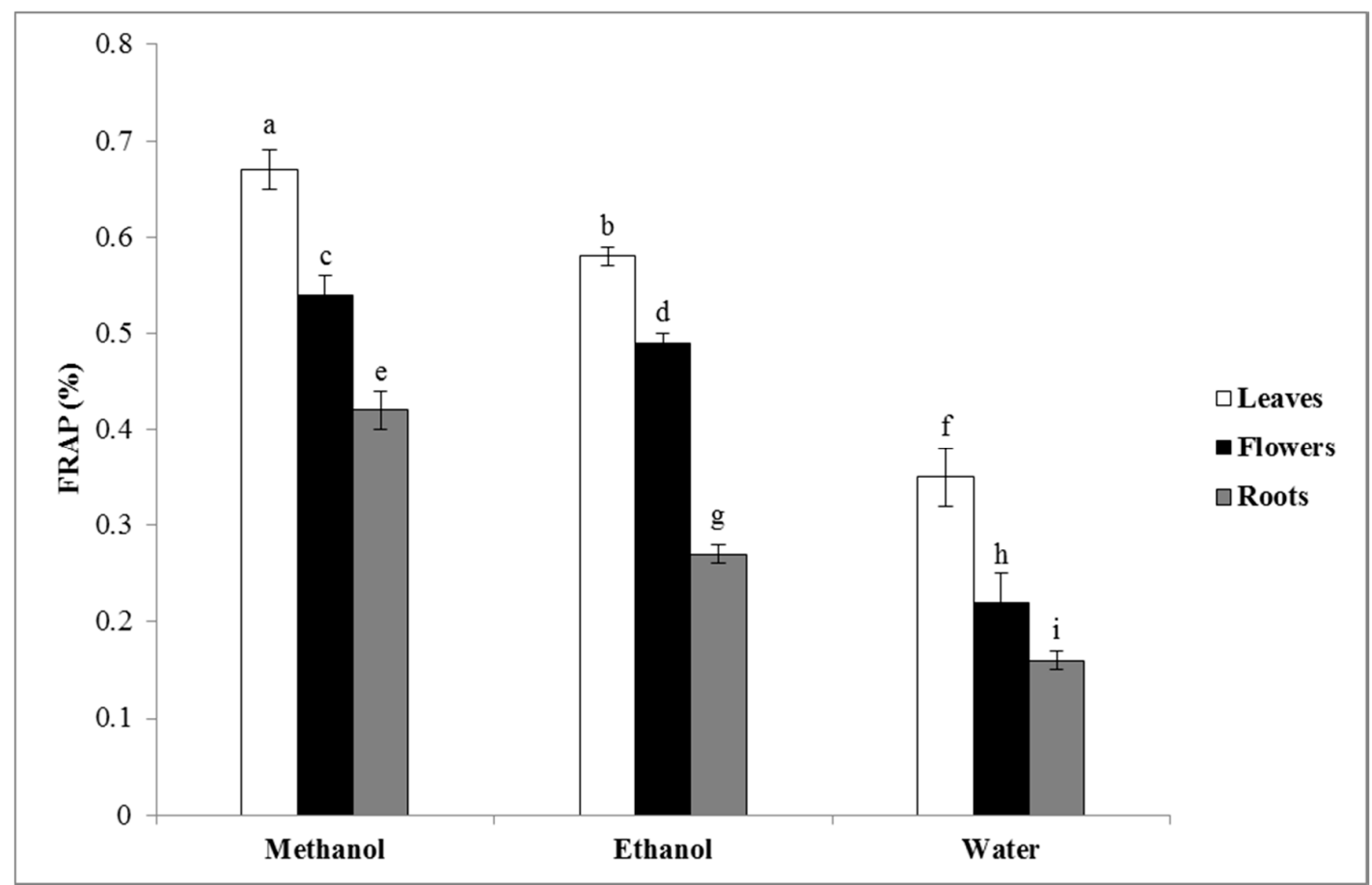

Figure 3. Ferric reducing antioxidant power (FRAP) values of the different extracts of Nepeta juncea. Columns belonging to the same dataset and labeled with different letters are significantly different, $p<0.05(n=3)$. 


\subsection{Cytotoxicity Activity}

The cytotoxicity activity results are summarized in Table 3. The N. juncea extracts exhibited a dose-dependent reduction in the survival of both cancer cells. According to the results, the methanolic extracts of $N$. juncea had the maximum cytotoxicity activity in both cancer cell lines, while the minimum cytotoxicity activity was observed for the water extracts. Skorić et al. [45] studied the cytotoxicity of Nepeta rtanjensis toward the HeLa, K562, A549, LS-174, and MDA-MB-231 cancer cell lines. They reported that the application of $N$. rtanjensis essential oil led to the emergence of morphological changes in the investigated cancer cell lines, and thus suggested that this oil may be applied as a potential anticancer therapy.

Table 3. Cytotoxic activity of Nepeta juncea extracts toward human cancer cell lines.

\begin{tabular}{|c|c|c|c|c|}
\hline \multirow{2}{*}{ Solvent } & \multirow{2}{*}{ Plant Part } & \multirow{2}{*}{ Concentration $(\mu \mathrm{g} / \mathrm{mL})$} & \multicolumn{2}{|c|}{ Viability (\%) } \\
\hline & & & MCF-7 & Hep-G2 \\
\hline \multirow{14}{*}{ Methanol } & \multirow{4}{*}{ Leaves } & 25 & $86.2 \pm 0.2$ & $88.6 \pm 0.4$ \\
\hline & & 50 & $75.1 \pm 0.5$ & $76.3 \pm 0.2$ \\
\hline & & 100 & $62.7 \pm 0.3$ & $64.2 \pm 0.3$ \\
\hline & & 200 & $55.9 \pm 0.1$ & $58.4 \pm 0.1$ \\
\hline & \multirow{5}{*}{ Flowers } & 0 & 100 & 100 \\
\hline & & 25 & $94.3 \pm 0.1$ & $96.7 \pm 0.5$ \\
\hline & & 50 & $84.7 \pm 0.2$ & $86.4 \pm 0.2$ \\
\hline & & 100 & $70.2 \pm 0.4$ & $73.9 \pm 0.1$ \\
\hline & & 200 & $66.1 \pm 0.2$ & $68.3 \pm 0.3$ \\
\hline & \multirow{5}{*}{ Roots } & 0 & 100 & 100 \\
\hline & & 25 & $95.5 \pm 0.5$ & $98.9 \pm 0.2$ \\
\hline & & 50 & $93.2 \pm 0.6$ & $95.6 \pm 0.4$ \\
\hline & & 100 & $89.1 \pm 0.4$ & $92.4 \pm 0.3$ \\
\hline & & 200 & $87.4 \pm 0.2$ & $89.2 \pm 0.2$ \\
\hline \multirow{15}{*}{ Ethanol } & \multirow{5}{*}{ Leaves } & 0 & 100 & 100 \\
\hline & & 25 & $91.2 \pm 0.1$ & $92.1 \pm 0.3$ \\
\hline & & 50 & $82.4 \pm 0.3$ & $84.3 \pm 0.2$ \\
\hline & & 100 & $70.3 \pm 0.2$ & $72.1 \pm 0.5$ \\
\hline & & 200 & $62.8 \pm 0.5$ & $65.6 \pm 0.4$ \\
\hline & \multirow{5}{*}{ Flowers } & 0 & 100 & 100 \\
\hline & & 25 & $95.9 \pm 0.4$ & $97.2 \pm 0.1$ \\
\hline & & 50 & $86.8 \pm 0.2$ & $89.2 \pm 0.2$ \\
\hline & & 100 & $72.7 \pm 0.1$ & $75.6 \pm 0.1$ \\
\hline & & 200 & $69.3 \pm 0.4$ & $71.3 \pm 0.1$ \\
\hline & \multirow{5}{*}{ Roots } & 0 & 100 & 100 \\
\hline & & 25 & $96.7 \pm 0.3$ & $99.2 \pm 0.2$ \\
\hline & & 50 & $94.2 \pm 0.2$ & $96.3 \pm 0.1$ \\
\hline & & 100 & $91.6 \pm 0.6$ & $94.2 \pm 0.2$ \\
\hline & & 200 & $89.2 \pm 0.5$ & $92.3 \pm 0.6$ \\
\hline
\end{tabular}


Table 3. Cont.

\begin{tabular}{|c|c|c|c|c|}
\hline \multirow{2}{*}{ Solvent } & \multirow{2}{*}{ Plant Part } & \multirow{2}{*}{ Concentration $(\mu \mathrm{g} / \mathrm{mL})$} & \multicolumn{2}{|c|}{ Viability (\%) } \\
\hline & & & MCF-7 & Hep-G2 \\
\hline \multirow{15}{*}{ Water } & \multirow{5}{*}{ Leaves } & 0 & 100 & 100 \\
\hline & & 25 & $96.3 \pm 0.7$ & $98.4 \pm 0.7$ \\
\hline & & 50 & $92.5 \pm 0.5$ & $94.2 \pm 0.3$ \\
\hline & & 100 & $88.3 \pm 0.3$ & $91.1 \pm 0.2$ \\
\hline & & 200 & $85.2 \pm 0.2$ & $87.3 \pm 0.4$ \\
\hline & \multirow{5}{*}{ Flowers } & 0 & 100 & 100 \\
\hline & & 25 & $97.6 \pm 0.5$ & $99.1 \pm 0.4$ \\
\hline & & 50 & $96.2 \pm 0.3$ & $97.6 \pm 0.6$ \\
\hline & & 100 & $91.4 \pm 0.7$ & $93.9 \pm 0.1$ \\
\hline & & 200 & $87.4 \pm 0.3$ & $89.6 \pm 0.3$ \\
\hline & \multirow{5}{*}{ Roots } & 0 & 100 & 100 \\
\hline & & 25 & $98.8 \pm 0.2$ & $99.7 \pm 0.4$ \\
\hline & & 50 & $96.2 \pm 0.1$ & $98.1 \pm 0.2$ \\
\hline & & 100 & $94.1 \pm 0.5$ & $96.3 \pm 0.5$ \\
\hline & & 200 & $93.8 \pm 0.3$ & $95.2 \pm 0.1$ \\
\hline \multirow{5}{*}{\multicolumn{2}{|c|}{ Vinblastine }} & 0 & 100 & 100 \\
\hline & & 25 & $51.6 \pm 0.2$ & $55.2 \pm 0.3$ \\
\hline & & 50 & $24.2 \pm 0.1$ & $19.5 \pm 0.5$ \\
\hline & & 100 & $9.4 \pm 0.4$ & $11.7 \pm 0.2$ \\
\hline & & 200 & $3.7 \pm 0.3$ & $4.6 \pm 0.1$ \\
\hline
\end{tabular}

MCF-7, human breast adenocarcinoma cells; Hep-G2, human hepatocellular carcinoma cells.

\subsection{Antifungal Activity}

From the results shown in Table 4, the best antifungal activity against the tested fungi was observed in the $N$. juncea methanolic extracts with minimum inhibitory concentration (MIC) values ranging from 25 to $100 \mu \mathrm{g} / \mathrm{mL}$. Candida albicans was more sensitive with an MIC value of 25, 50, and $50 \mu \mathrm{g} / \mathrm{mL}$ for the methanolic extracts of the leaves, flowers, and roots, respectively. The minimum fungicidal concentration (MFC) was in the range of $50-100 \mu \mathrm{g} / \mathrm{mL}$ for the methanolic extracts. The antifungal activities of the essential oils isolated from other Nepeta species have been reported elsewhere [46,47]. According to the results of the current study, the main compounds of the $N$. juncea extracts were 1,8-cineole and $4 \mathrm{a} \alpha-7 \alpha-7 \mathrm{a} \alpha$-Nepetalactone. Regarding previous studies, these compounds could be considered as the active components responsible for the extracts' antifungal activities [48,49].

\subsection{Antibacterial Activity}

Determination of the Minimum Inhibitory Concentration (MIC) and the Minimum Bactericidal Concentration $(\mathrm{MBC})$

The results in Table 5 show that the best antibacterial activity against the tested bacteria was from the $N$. juncea methanolic extracts with MIC values ranging from 25 to $100 \mu \mathrm{g} / \mathrm{mL}$. Among them, S. aureus and B. cereus were the most sensitive bacteria with an MIC value of 25,25 , and $50 \mu \mathrm{g} / \mathrm{mL}$ for the methanolic extracts of the leaves, flowers, and roots, respectively. The results show that the MBC was in the range of $50-200 \mu \mathrm{g} / \mathrm{mL}$ for the methanolic extracts. According to the results, the extracts 
had lower MIC and MBC values against all tested Gram-positive bacteria compared to Gram-negative bacteria. The lower MIC and MBC values indicate the higher antibacterial activity of the extracts on the tested bacteria strains [50].

Table 4. Antifungal activity of the Nepeta juncea extracts.

\begin{tabular}{cccccc}
\hline \multirow{2}{*}{ Solvent } & Plant Part & \multicolumn{2}{c}{ Candida albicans } & \multicolumn{2}{c}{ C. glabrata } \\
\cline { 2 - 6 } & $\begin{array}{c}\text { MIC } \\
(\mu \mathrm{g} / \mathrm{mL})\end{array}$ & $\begin{array}{c}\text { MFC } \\
(\mu \mathrm{g} / \mathrm{mL})\end{array}$ & $\begin{array}{c}\text { MIC } \\
(\mu \mathrm{g} / \mathrm{mL})\end{array}$ & $\begin{array}{c}\text { MFC } \\
(\mu \mathrm{g} / \mathrm{mL})\end{array}$ \\
\hline \multirow{3}{*}{ Methanol } & Leaves & 25 & 50 & 50 & 50 \\
\cline { 2 - 6 } & Flowers & 50 & 50 & 50 & 100 \\
\cline { 2 - 6 } & Roots & 50 & 100 & 100 & 100 \\
\hline \multirow{3}{*}{ Ethanol } & Leaves & 50 & 100 & 50 & 100 \\
\cline { 2 - 6 } & Flowers & 100 & 100 & 100 & 200 \\
\cline { 2 - 6 } & Roots & 100 & 200 & 200 & 200 \\
\hline \multirow{3}{*}{ Water } & Leaves & 100 & 200 & 100 & 200 \\
\cline { 2 - 6 } & Flowers & 200 & 200 & 200 & - \\
\cline { 2 - 6 } & Roots & 200 & - & 200 & 25 \\
\hline \multicolumn{2}{r}{ Fluconazole } & 25 & 25 & 25 & - \\
\hline
\end{tabular}

MIC, minimum inhibitory concentration; MFC, minimum fungicidal concentration.

Table 5. Minimum inhibitory concentration (MIC) and minimum bactericidal concentration (MBC) values of the Nepeta juncea extracts against the tested bacteria.

\begin{tabular}{|c|c|c|c|c|c|c|c|c|c|}
\hline \multirow[b]{2}{*}{ Solvent } & \multirow{2}{*}{$\begin{array}{c}\text { Plant } \\
\text { Part }\end{array}$} & \multicolumn{2}{|c|}{ Staphylococcus aureus } & \multicolumn{2}{|c|}{ Bacillus cereus } & \multicolumn{2}{|c|}{ Escherichia coli } & \multicolumn{2}{|c|}{ Shigella flexneri } \\
\hline & & $\begin{array}{c}\text { MIC } \\
(\mu \mathrm{g} / \mathrm{mL})\end{array}$ & $\begin{array}{c}\text { MBC } \\
(\mu \mathrm{g} / \mathrm{mL})\end{array}$ & $\begin{array}{c}\text { MIC } \\
(\mu \mathrm{g} / \mathrm{mL})\end{array}$ & $\begin{array}{c}\text { MBC } \\
(\mu \mathrm{g} / \mathrm{mL})\end{array}$ & $\begin{array}{c}\text { MIC } \\
(\mu \mathrm{g} / \mathrm{mL})\end{array}$ & $\begin{array}{c}\text { MBC } \\
(\mu \mathrm{g} / \mathrm{mL})\end{array}$ & $\begin{array}{c}\text { MIC } \\
(\mu \mathrm{g} / \mathrm{mL})\end{array}$ & $\begin{array}{c}\text { MBC } \\
(\mu \mathrm{g} / \mathrm{mL})\end{array}$ \\
\hline \multirow{3}{*}{ Methanol } & Leaves & 25 & 50 & 25 & 50 & 50 & 100 & 50 & 100 \\
\hline & Flowers & 25 & 50 & 25 & 50 & 50 & 100 & 50 & 100 \\
\hline & Roots & 50 & 100 & 50 & 100 & 100 & 200 & 100 & 200 \\
\hline \multirow{3}{*}{ Ethanol } & Leaves & 50 & 100 & 50 & 100 & 100 & 200 & 100 & 200 \\
\hline & Flowers & 50 & 100 & 50 & 100 & 100 & 200 & 100 & 200 \\
\hline & Roots & 100 & 200 & 100 & 200 & 200 & - & 200 & - \\
\hline \multirow{3}{*}{ Water } & Leaves & 50 & 100 & 50 & 100 & 100 & 200 & 100 & 200 \\
\hline & Flowers & 100 & 200 & 100 & 200 & 200 & - & 200 & - \\
\hline & Roots & 100 & 200 & 100 & 200 & 200 & - & 200 & - \\
\hline
\end{tabular}

\section{Materials and Methods}

\subsection{Preparation of the Plant Extracts}

The roots, leaves, and flowers of $N$. juncea Benth. were collected from the Saravan rangelands, Sistan, and Baluchesrtan, Iran. The genus and species of this plant were identified at the Department of Botany, Shahid Beheshti University of Medical Sciences, Tehran, Iran, where a voucher specimen (No. 842) was deposited. The different plant parts were dried in an oven at $40{ }^{\circ} \mathrm{C}$ for $72 \mathrm{~h}$ and then ground to a fine powder using an electric grinder (Pars Khazar, Tehran, Iran). The plant extracts were obtained by magnetic stirring of $2.5 \mathrm{~g}$ of powdered dry matter with $50 \mathrm{~mL}$ of solvent (methanol, $96 \%$ ethanol, and water) for $40 \mathrm{~min}$ at room temperature $\left(24 \pm 2{ }^{\circ} \mathrm{C}\right)$. The extracts were kept for $24 \mathrm{~h}$ at $4{ }^{\circ} \mathrm{C}$, filtered through Whatman filter paper No. 1, and the filtrate evaporated to complete dryness 
under vacuum. A stock solution of different extracts $(1 \mathrm{mg} / \mathrm{mL})$ dissolved in methanol was used for the experiments.

\subsection{Total Phenol Concentration}

Total phenol concentration was determined using the Folin-Ciocalteu reagent, as described by Dewanto et al. [51]. Briefly, an aliquot of the diluted extract was added to $0.5 \mathrm{~mL}$ of distilled water and then completely mixed with $0.125 \mathrm{~mL}$ of the Folin-Ciocalteu reagent. After $3 \mathrm{~min}, 1.25 \mathrm{~mL}$ of $5 \%(w / v)$ of $\mathrm{Na}_{2} \mathrm{CO}_{3}$ was added and the resulting solution mixed thoroughly. For adjusting the final volume to $4 \mathrm{~mL}$, distilled water was added. Finally, the resulting mixture was kept in darkness at room temperature for $2 \mathrm{~h}$, and then the absorbance of the mixture was recorded at $760 \mathrm{~nm}$ using a UV-Vis spectrophotometer (UV-1800 240 V, Shimadzu Corporation, Kyoto, Japan). The total phenol value is represented as milligrams of gallic acid equivalents per gram of dry weight (mg GAE/g dry weight). A standard calibration curve was drawn at the same operating conditions using gallic acid $\left(20-200 \mu \mathrm{g} / \mathrm{mL}, \mathrm{y}=0.0089 \mathrm{x}-0.0003, \mathrm{R}^{2}=0.992\right)$ as a positive control.

\subsection{Total Flavonoid Concentration}

The total flavonoid content was determined based on the colorimetric assay described by Chang et al. [52] with minor modifications. In summary, $0.5 \mathrm{~mL}$ of each extract was separately mixed with $1.5 \mathrm{~mL}$ of methanol, $0.1 \mathrm{~mL}$ of potassium acetate $(1 \mathrm{~mol} / \mathrm{L}), 0.1 \mathrm{~mL}$ of $\mathrm{AlCl}_{3}(10 \%)$, and $2.8 \mathrm{~mL}$ of distilled water. The resulting mixture was kept at room temperature for $30 \mathrm{~min}$. The absorbance of the mixture was recorded at $415 \mathrm{~nm}$ by using a UV-Vis spectrophotometer. Quantitative determination of the flavonoid content was calculated as quercetin from a calibration curve. Quercetin was used as the standard $\left(10-100 \mu \mathrm{g} / \mathrm{mL}, \mathrm{y}=0.0092 \mathrm{x}-0.034, \mathrm{R}^{2}=0.996\right)$, and the results are expressed as milligrams of quercetin equivalents per gram of dry weight (mg QE/g dry weight).

\subsection{Total Anthocyanin Concentration}

The total anthocyanin concentration was measured based on the $\mathrm{pH}$ differential method explained by Vega-Arroy et al. [53] with minor modifications. Ten milliliters of each extract were mixed with hydrochloric acid $(1 \mathrm{M})$ or sodium hydroxide $(1 \mathrm{M})$ to reach a $\mathrm{pH}$ of 1 or 4.5 . The absorbance was recorded using a UV-Vis spectrophotometer at 520 and $700 \mathrm{~nm}$. Cyanidin-3-glucoside was used as the standard $\left(5-50 \mu \mathrm{g} / \mathrm{mL}, \mathrm{y}=0.0201 \mathrm{x}+0.0168, \mathrm{R}^{2}=0.991\right)$. The concentration of total anthocyanin was determined as cyanidin-3-glucoside equivalents (mg/100 g) using Equations (1) and (2):

$$
\begin{aligned}
\mathrm{A}= & (\mathrm{A} 520 \mathrm{~nm}-\mathrm{A} 700 \mathrm{~nm}) \mathrm{pH} 1.0-(\mathrm{A} 520 \mathrm{~nm}-\mathrm{A} 700 \mathrm{~nm}) \mathrm{pH} 4.5 \\
& \text { Total anthocyanin }(\mathrm{mg} / 100 \mathrm{~g})=(\mathrm{A} \times \mathrm{MW} \times \mathrm{DF} \times 1000) / \varepsilon \times 1
\end{aligned}
$$

where $\mathrm{A}$ is the difference in absorbance; $\mathrm{MW}$ (molecular weight) $=449.2 \mathrm{~g} / \mathrm{mol}$ for cyanidin-3-glucoside; DF is the dilution factor; 1 = quartz cell pathway $(1 \mathrm{~cm})$; and $\varepsilon$ is the molar extinction coefficient for cyanidin-3-glucoside $\left(26,900 \mathrm{M}^{-1} \mathrm{~cm}^{-1}\right)$.

\subsection{Total Tannin Concentration}

The total tannin concentration was determined based on the method of Sun et al. [54]. In brief, $2 \mathrm{~mL}$ of vanillin solution $(4 \%)$ in methanol and $1.5 \mathrm{~mL}$ of concentrated $\mathrm{HCl}$ were added to $50 \mu \mathrm{L}$ of the diluted sample. After $25 \mathrm{~min}$, the absorption of the reaction mixture was determined at $500 \mathrm{~nm}$ using a UV-Vis spectrophotometer. Methanol was used as the blank, and catechin was used as the standard $\left(20-120 \mu \mathrm{g} / \mathrm{mL}, \mathrm{y}=0.0036 \mathrm{x}+0.0011, \mathrm{R}^{2}=0.994\right)$. The total condensed tannin content is represented as $\mathrm{mg}(+)$-catechin/g dry weight. 


\subsection{Gas Chromatography-Mass Spectrometry Analysis}

Gas chromatography-mass spectrometry analysis was carried out on a GCMS-QP2010 system (Shimadzu, Tokyo, Japan). Hexane ( $\geq 99 \%$; Sigma-Aldrich, Germany) was used to dilute $20 \mu \mathrm{L}$ of each extract to $1 \mathrm{~mL}$. The used column was Rtx-5MS (Restek, Bellefonte, PA, USA) (30 m $\times 0.25 \mathrm{~mm}$ i.d. $\times$ $0.25 \mu \mathrm{L}$ film thickness). The helium flow rate (99.999\%; AGA Lithuania) carrier gas was adjusted at $1.23 \mathrm{~mL} / \mathrm{min}$. After injection, the temperature of the oven was retained at $40{ }^{\circ} \mathrm{C}$ for $2 \mathrm{~min}$; then, it was programmed to increase by $3{ }^{\circ} \mathrm{C} / \mathrm{min}$ until it reached $210^{\circ} \mathrm{C}$, at which time the column was retained for $10 \mathrm{~min}$. The ratio of the split was 1:10. Detection was performed by 70-eV electron ionization. The compounds were identified using the mass spectra library (NIST 14) and the similarities of the mass spectra with the mass spectral data from the literature [55].

\subsection{Antioxidant Activity}

The antioxidant activity of the extracts was quantified as radical scavenging capacity against 2,2-diphenyl-1-picrylhydrazyl radical (DPPH) following the method of Sharifi-Rad et al. [56]. Different concentrations of extracts $(5,10,50$, and $100 \mu \mathrm{g} / \mathrm{mL})$ were added to $0.5 \mathrm{~mL}$ of $0.2 \mathrm{mmol} \mathrm{L}{ }^{-1}$ $\mathrm{DPPH}-$ methanol solution and left at room temperature $\left(25 \pm 2{ }^{\circ} \mathrm{C}\right)$ for $45 \mathrm{~min}$. The absorbance of the resulting solution was recorded using a UV-Vis spectrophotometer at $517 \mathrm{~nm}$. The percentage inhibition of the free radical DPPH was calculated using Equation (3).

$$
\text { Antioxidant Activity }(\%)=\left(\mathrm{A}_{\text {blank }}-\mathrm{A}_{\text {sample }} / \mathrm{A}_{\text {blank }}\right) \times 100
$$

where $A_{\text {blank }}$ is the absorbance of the control (consisting of the solvent and DPPH) and $A_{\text {sample }}$ is the absorbance in the presence of the plant extract. Ascorbic acid solutions $(5,10,50$, and $100 \mu \mathrm{g} / \mathrm{mL})$ were used as standard and the $\mathrm{IC}_{50}$ values were calculated from the percent inhibition. The results are expressed as $\mathrm{IC}_{50}$ values (e.g., the concentration of the extract required to scavenge $50 \%$ of the DPPH radical).

\subsection{Ferric Reducing Antioxidant Power (FRAP) Assay}

The FRAP assay was performed based on the method explained previously [57]. To prepare the FRAP reagent, $300 \mathrm{mM}$ sodium acetate buffer (pH 3.6, $10 \mathrm{~mL}$ ) was added to $20 \mathrm{mM}$ iron (III) chloride $(1 \mathrm{~mL})$ and $10 \mathrm{mM}$ TPTZ (2,4,6-tripyridyl-S-triazine) solution in $40 \mathrm{mM}$ hydrochloric acid $(1 \mathrm{~mL})$. This reagent was used in a water bath at $37^{\circ} \mathrm{C}$. The sample $(20 \mu \mathrm{L})$ was mixed with the FRAP reagent $(150 \mu \mathrm{L})$. The absorbance was immediately recorded at $593 \mathrm{~nm}$. The FRAP value was determined using Equation (4).

$$
\text { FARP value }(\%)=\left[\left(\mathrm{A}_{\mathrm{s}}-\mathrm{A}_{\mathrm{b}}\right) /\left(\mathrm{A}_{\mathrm{c}}-\mathrm{A}_{\mathrm{b}}\right)\right] \times 2
$$

where $A_{s}$ is the absorbance of the sample; $A_{b}$ is the absorbance of the blank, reacted with distilled water $(20 \mu \mathrm{L})$ and FRAP reagent $(150 \mu \mathrm{L})$; and $\mathrm{A}_{\mathrm{c}}$ is the absorbance of the positive control, reacted with ascorbic acid $(20 \mu \mathrm{L})$ and the FRAP reagent $(150 \mu \mathrm{L})$.

\subsection{Cytotoxicity Activity}

\subsubsection{Human Cancer Cell Lines}

The human breast adenocarcinoma (MCF-7) cells (ATCC $\left(H T B 22^{\mathrm{TM}}\right.$ ) and the human hepatocellular

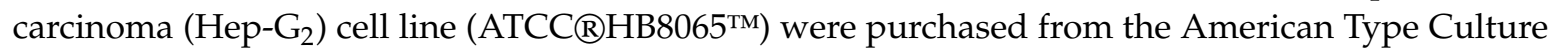
Collection (ATCC, Rockville, MD, USA). The cells were cultivated in Dulbecco's modified Eagle's Medium accompanied by L-glutamine (2\%), HEPES ( $\mathrm{N}$-2-hydroxyethylpiperazine- $\mathrm{N}$-2-ethane sulfonic acid) buffer, heat-inactivated fetal bovine serum $(10 \%)$, and $40 \mu \mathrm{g} / \mathrm{mL}$ gentamicin (Sigma-Aldrich, St. Louis, MO, USA). The cells were kept at in a humidified atmosphere with $\mathrm{CO}_{2}(5 \%)$ at $37^{\circ} \mathrm{C}$ and were sub-cultured four times a week. 


\subsubsection{Cytotoxicity Assay}

The cytotoxicity of $N$. juncea extracts toward the cancer cells was investigated using the crystal violet staining method as explained previously [58]. Briefly, 96-well tissue culture microplates were used for the incubation of the cells $\left(1 \times 10^{4}\right.$ cells per well supplemented with $100 \mu \mathrm{L}$ of growth medium). Various concentrations of the $N$. juncea extracts $(0,25,50,100$, and $200 \mu \mathrm{g} / \mathrm{mL})$ were added after $24 \mathrm{~h}$ of seeding at $37^{\circ} \mathrm{C}$. Two-fold serial dilutions of the extracts were added to confluent cell monolayers into the 96-well microtiter plates. The incubation of the plates was performed at $37^{\circ} \mathrm{C}$ for $48 \mathrm{~h}$ in a humidified incubator with $\mathrm{CO}_{2}(5 \%)$. The viable cells were measured by the colorimetric method. In brief, the medium was aspirated and crystal violet solution in methanol $(2 \% v / v)$ was added to each well. Afterward, $0.2 \mathrm{~mL}$ of glacial acetic acid-ethanol solution $(1.0 \mathrm{~mL}$ glacial acetic acid per $100 \mathrm{~mL}$ $70 \%$ ethanol) was added to each well and mixed completely. The absorbance was measured using an automatic microplate reader at $595 \mathrm{~nm}$. Vinblastine sulfate $(0,25,50,100$, and $200 \mu \mathrm{g} / \mathrm{mL})$ was considered as a standard anticancer drug.

\subsection{Antifungal Activity}

\subsubsection{Strains and Media}

The antifungal activity of the $N$. juncea extracts was evaluated on oral pathogens, including Candida albicans (ATCC 13803) and C. glabrata (ATCC 90030). The strains were cultured under constant shaking (200 rpm) at $30{ }^{\circ} \mathrm{C}$ in yeast-extract peptone dextrose (YPD) liquid medium consisting of $1 \%$ $(w / v)$ yeast extract, $2 \%(w / v)$ peptone, and $2 \%(w / v)$ dextrose.

\subsubsection{Antifungal Susceptibility Test}

The antifungal susceptibility test was carried out on the strains based on the broth microdilution procedure, as explained by Quan et al. [59]. The initial concentration of fungi suspended in RPMI 1640 media (Sigma, St. Louis, MO, USA) was about $10^{3}$ cells $/ \mathrm{mL}$, and the initial concentration of the $N$. juncea extracts ranged from 25 to $200 \mu \mathrm{g} / \mathrm{mL}$. The wells that included fungi inoculum without any extracts were considered as negative control, and fluconazole $(2-200 \mu \mathrm{g} / \mathrm{mL})$ was used as a reference or positive control. The 96 -well plates were incubated for $24-48 \mathrm{~h}$ at $35^{\circ} \mathrm{C}$. The minimum inhibitory concentrations (MICs) were determined using optical density. Finally, $100 \mu \mathrm{L}$ of the culture from each well showing no visible growth was sub-cultured on Sabouraud dextrose agar (Merck, Darmstadt, Germany) to measure the minimum fungicidal concentrations (MFCs).

\subsection{Antibacterial Activity}

\subsubsection{Bacterial Strain Preparation}

Different American-Type Cell Culture (ATCC) reference bacterial strains, including Staphylococcus aureus (ATCC: 25923), Bacillus cereus (ATCC: 11778), Escherichia coli (ATCC: 25922), and Shigella flexneri (ATCC: 12022), were obtained from the Iranian microbial collections of the Pasteur Institute of Iran. The bacterial strains were incubated for $24 \mathrm{~h}$ at $37^{\circ} \mathrm{C}$ on nutrient broth. All bacteria strains were adjusted to $0.5 \mathrm{McFarland}$ standard by the optical density (OD) method at $620 \mathrm{~nm}\left(1.5 \times 10^{8} \mathrm{CFU} / \mathrm{mL}\right)$, as described by Sharifi-Rad et al. [60].

\subsubsection{Determination of the Minimum Inhibitory Concentration (MIC)}

The micro-broth dilution method was used to measure the minimum inhibitory concentrations (MICs) of the extracts against the tested bacteria, as recommended by the Clinical and Laboratory Standards Institute [61]. The concentrations of the extracts considered for MICs ranged from 25 to $200 \mu \mathrm{g} / \mathrm{mL}$. The test was carried out using polystyrene 96-well plates. Two-fold serial dilutions of the extracts were prepared in cation-adjusted Mueller-Hinton broth. Then, $50 \mu \mathrm{L}$ of Mueller-Hinton broth and $50 \mu \mathrm{L}$ of the different concentrations of the extracts were used for preparing each inoculum. 
The starting inoculum for each strain was $1.5 \times 10^{8} \mathrm{CFU} / \mathrm{mL}$, and the wells that included bacterial inoculum without any extracts were considered as the control. Plates were incubated for $24 \mathrm{~h}$ at $37^{\circ} \mathrm{C}$. The lowest concentration of the extracts at which the microorganisms showed no visible growth was considered as the MIC.

\subsubsection{Determination of the Minimum Bactericidal Concentration (MBC)}

Determination of the MBC values was performed based on a method described by the Clinical and Laboratory Standards Institute [61]. After $24 \mathrm{~h}$ of incubation, $100 \mu \mathrm{L}$ of the culture from each well of the micro-broth test was sub-cultured on Mueller-Hinton agar plates, which were further incubated for $24 \mathrm{~h}$ at $37^{\circ} \mathrm{C}$. The MBC was defined as the lowest concentration of the extracts at which there was no sign of bacterial growth.

\subsection{Statistical Analysis}

All experiments were performed in triplicate. Data were analyzed by the statistical software package SPSS v 11.5 (IBM Corporation, Armonk, NY, USA). The analysis of variance (ANOVA) and Duncan's multiple range methods were used to compare any significant differences between samples and solvents. The results are presented as means values \pm standard deviations (SD).

\section{Conclusions}

The leaf extracts of $N$. juncea showed higher antioxidant, cytotoxic, antifungal, and antibacterial activities than the flower and root extracts, and the methanolic extracts of the leaves had the highest of these activities. This extract also showed high phenolic, flavonoid, anthocyanin, and tannin contents. It could be hypothesized that these compounds may be responsible for the extract's biological activities. To the best of our knowledge, this is the first report on the antioxidant, cytotoxic, antifungal, and antibacterial activities of $N$. juncea extracts. The results of the current study confirm that $N$. juncea has antioxidant, cytotoxic, antifungal, and antibacterial activities and that it may be appropriate as a phytopharmaceutical ingredient.

Author Contributions: Conceptualization, M.S.-R.; methodology, M.S.-R.; validation, M.S.-R.; formal analysis, M.S.-R.; investigation, M.S.-R.; resources, M.S.-R.; data curation, M.S.-R. and J.M.Á.-S.; writing—original draft preparation, M.S.-R. and J.M.Á.-S.; writing—review and editing, M.S.-R., F.E., S.F., and J.M.Á.-S.; visualization, M.S.-R.; supervision, M.S.-R. and J.M.Á.-S.; project administration, M.S.-R.; and funding acquisition, M.S.-R. All authors have read and agreed to the published version of the manuscript.

Funding: This research was funded by the University of Zabol, Zabol, Iran (grant number: UOZ-GR-9618-8).

Conflicts of Interest: The authors declare no financial or other conflicts of interest.

\section{References}

1. Mollica, A.; Costante, R.; Akdemir, A.; Carradori, S.; Stefanucci, A.; Macedonio, G.; Ceruso, M.; Supuran, C.T. Exploring new Probenecid-based carbonic anhydrase inhibitors: Synthesis, biological evaluation and docking studies. Bioorg. Med. Chem. 2015, 23, 5311-5318. [CrossRef] [PubMed]

2. Picot, M.C.; Zengin, G.; Mollica, A.; Stefanucci, A.; Carradori, S.; Mahomoodally, M. In vitro and in silico studies of mangiferin from Aphloia theiformis on key enzymes linked to diabetes type 2 and associated complications. Med. Chem. 2017, 13, 633-640. [CrossRef] [PubMed]

3. Mercy, R.; David Udo, E. Natural products as lead bases for drug discovery and development. Res. Rep. Med. Sci. 2018, 2, 1-2.

4. Nandhakumar, E.; Indumathi, P. In vitro antioxidant activities of methanol and aqueous extract of Annona squamosa (L.) fruit pulp. J. Acupunct. Meridian Stud. 2013, 6, 142-148. [CrossRef] [PubMed]

5. Embuscado, M.E. Spices and herbs: Natural sources of antioxidants-a mini review. J. Funct. Foods. 2015, 18, 811-819. [CrossRef] 
6. Mollica, A.; Stefanucci, A.; Macedonio, G.; Locatelli, M.; Luisi, G.; Novellino, E.; Zenginc, G. Chemical composition and biological activity of Capparis spinosa L. from Lipari Island. S. Afr. J. Bot. 2019, 120, 135-140. [CrossRef]

7. Altemimi, A.; Lakhssassi, N.; Baharlouei, A.; Watson, D.G.; Lightfoot, D.A. Phytochemicals: Extraction, isolation, and identification of bioactive compounds from plant extracts. Plants 2017, 6, 42. [CrossRef]

8. Lobo, V.; Patil, A.; Phatak, A.; Chandra, N. Free radicals, antioxidants and functional foods: Impact on human health. Pharmacogn. Rev. 2010, 4, 118-126. [CrossRef]

9. Nimse, S.B.; Pal, D. Free radicals, natural antioxidants, and their reaction mechanisms. RSC Adv. 2015, 5, 27986. [CrossRef]

10. Finkel, T.; Holbrook, N.J. Oxidants, oxidative stress and the biology of ageing. Nature 2020, 408, $239-247$. [CrossRef]

11. Maritim, A.C.; Sanders, R.A.; Watkins, J.B. Diabetes, oxidative stress, and antioxidants: A review. J. Biochem. Mol. Toxicol. 2003, 17, 24-38. [CrossRef] [PubMed]

12. Klaunig, J.E.; Kamendulis, L.M. The role of oxidative stress in carcinogenesis. Annu. Rev. Pharmacol. Toxicol. 2004, 44, 239-267. [CrossRef] [PubMed]

13. Butterfield, D.A. Amyloid beta-peptide (1-42)-induced oxidative stress and neurotoxicity: Implications for neurodegeneration in Alzheimer's disease brain. A review. Free Radic. Res. 2002, 36, 1307-1313. [CrossRef] [PubMed]

14. Zhivich, A. Fighting bacterial resistance: Approaches, challenges, and opportunities in the search for new antibiotics. Part 1. Antibiotics used in clinical practice: Mechanisms of action and the development of bacterial resistance. Microbiol. Indep. Res. J. 2017, 4, 31-51. [CrossRef]

15. Tsuruga, M.; Nakajima, H.; Magae, J. Immunosuppressive activity of 4-O-methylascochlorin. J. Antibiot. 2007, 60, 20-26. [CrossRef]

16. Rojas, J.J.; Ochoa, V.J.; Ocampo, S.A.; Munoz, J.F. Screening for antimicrobial activity of ten medicinal plants used in Colombian folkloric medicine: A possible alternative in the treatment of non-nosocomial infections. BMC Complement Altern. Med. 2006, 6, 2. [CrossRef]

17. Naqvi, S.A.R.; Nadeem, S.; Komal, S.; Naqvi, S.A.A.; Mubarik, M.S.; Qureshi, S.Y.; Ahmad, S.; Abbas, A.; Zahid, M.; Khan, N.U.H.; et al. Antioxidants: Natural Antibiotics, 1st ed.; IntechOpen: London, UK, 2019; pp. 1-17.

18. Mottamal, M.; Zheng, S.; Huang, T.L.; Wang, G. Histone deacetylase inhibitors in clinical studies as templates for new anticancer agents. Molecules 2015, 20, 3898-3941. [CrossRef]

19. Sharifi-Rad, J.; Sharifi-Rad, M.; Hoseini-Alfatemi, S.M.; Iriti, M.; Sharifi-Rad, M.; Sharifi-Rad, M. Composition, Cytotoxic and Antimicrobial Activities of Satureja intermedia C.A.Mey Essential Oil. Int. J. Mol. Sci. 2015, 16, 17812-17825. [CrossRef]

20. Coutinho, H.D.M. Factors influencing the virulence of Candida spp. West Indian Med. J. 2009, 58, 160-163.

21. Dignani, M.C.; Solomkin, J.S.; Anaissie, E. Candida. In Medical Mycology; Anaissie, E., McGinnis, M.R., Pfaller, M.A., Eds.; Churchill Livingstone: Philadelphia, PA, USA, 2003; pp. 195-239.

22. Al-Bayati, F.A. Isolation and identification of antimicrobial compound from Mentha longifolia L. leaves grown wild in Iraq. Ann. Clin. Microbiol. Antimicrob. 2009, 8, 20. [CrossRef]

23. Alves, P.M.; Queiroz, L.M.; Pereira, J.V.; Pereira Mdo, S. In vitro antimicrobial, antiadherent and antifungal activity of Brazilian medicinal plants on oral biofilm microorganisms and strains of the genus Candida. Rev. Soc. Bras Med. Trop. 2009, 42, 222-224. [CrossRef] [PubMed]

24. Salehi, B.; Valussi, M.; Jugran, A.K.; Martorell, M.; Ramírez-Alarcón, K.; Stojanović-Radić, Z.Z.; Antolak, H.; Kregiel, D.; Mileski, K.S.; Sharifi-Rad, M.; et al. Nepeta species: From farm to food applications and phytotherapy. Trends Food Sci. Technol. 2018, 80, 104-122. [CrossRef]

25. Adiguzel, A.; Ozer, H.; Sokmen, M.; Gulluce, M.; Sokmen, A.; Kilic, H.; Sahin, F.; Baris, O. Antimicrobial and antioxidant activity of the essential oil and methanol extract of Nepeta cataria. Pol. J. Microbiol. 2009, 58, 69-76. [PubMed]

26. Formisano, C.; Rigano, D.; Senatore, F. Chemical constituents and biological activities of Nepeta species. Chem Biodivers. 2011, 8, 1783-1818. [CrossRef]

27. Emami, S.A.; Yazdian-Robati, R.; Sadeghi, M.; Baharara, J.; Amini, E.; Salek, F.; Tayarani Najaran, Z. Inhibitory effects of different fractions of Nepeta satureioides on melanin synthesis through reducing oxidative stress. Res. Pharm. Sci. 2017, 12, 160-167. [CrossRef] 
28. Marinova, E.M.; Yanishlieva, N.V. Antioxidative activity of extracts from selected species of the family Lamiaceae in sunflower oil. Food Chem. 1997, 58, 245-248. [CrossRef]

29. Zarena, A.S.; Sankar, K.U. A study of antioxidant properties from Garcinia mangostana L. pericarp extract. Acta Sci. Poln. Technol. Aliment. 2009, 8, 23-34.

30. Johari, M.A.; Khong, H.Y. Total phenolic content and antioxidant and antibacterial activities of pereskia bleo. Adv. Pharm. Sci. 2019, 7428593, 1-4. [CrossRef]

31. Kopjar, M.; Orsolic, M.; Pilizota, V. Anthocyanins, phenols, and antioxidant activity of sour cherry puree extracts and their stability during storage. Int. J. Food Prop. 2014, 17, 1393-1405. [CrossRef]

32. Silva, S.; Costa, E.M.; Calhau, C.; Morais, R.M.; Pintado, M.E. Anthocyanin extraction from plant tissues: A review. Crit. Rev. Food Sci. Nutr. 2017, 57, 3072-3083. [CrossRef]

33. Markom, M.; Hasan, M.; Daud, W.R.W.; Singh, H.; Jahim, J.M. Extraction of hydrolysable tannins from Phyllanthus niruri Linn.: Effects of solvents and extraction methods. Sep. Purif. Technol. 2007, 52, 487-496. [CrossRef]

34. Widyawati, P.S.; Dwi, T.; Budianta, W.; Kusuma, F.A.; Wijaya, E.L. Difference of solvent polarity to phytochemical content and antioxidant activity of Pluchea indicia less leaves extracts. Int. J. Pharmacogn. Phytochem. Res. 2014, 6, 850-855.

35. Şimşek, M.; Duman, R. Investigation of Effect of 1,8-cineole on antimicrobial activity of chlorhexidine gluconate. Pharmacognosy Res. 2017, 9, 234-237. [CrossRef] [PubMed]

36. da Silva, A.C.R.; Lopes, P.M.; de Azevedo, M.M.B.; Costa, D.C.M.; Alviano, C.S.; Alviano, D.S. Biological Activities of $\alpha$-Pinene and $\beta$-Pinene Enantiomers. Molecules 2012, 17, 6305-6316. [CrossRef]

37. Shafaghat, A.; Khodamali, O. Nepetalactone content and antibacterial activity of the essential oils from different parts of Nepeta persica. Nat. Prod. Commun. 2009, 5, 625-628.

38. Cox, S.D.; Mann, C.M.; Markham, J.L. Interactions between components of the essential oil of Melaleuca alternifolia. J. Appl. Microbiol. 2001, 91, 492-497. [CrossRef]

39. Shafaghat, A.; Salimi, F.; Akhlaghi, H. Chemical composition of the essential oil isolated from flower, leaf, stem and root of Nepeta sintenisii Bornm. from Iran. J. Essent. Oil-Bear. Plants. 2008, 11, 391-396. [CrossRef]

40. Gruz, J.; Ayaz, F.A.; Torun, H.; Strnad, M. Phenolic acid content and radical scavenging activity of extracts from medlar (Mespilus germanica L.) fruit at different stages of ripening. Food Chem. 2011, 124, 271-277. [CrossRef]

41. Aryal, S.; Baniya, M.K.; Danekhu, K.; Kunwar, P.; Gurung, R.; Koirala, N. Total phenolic content, flavonoid content and antioxidant potential of wild vegetables from western Nepal. Plants 2019, 8, 96. [CrossRef]

42. Liu, X.; Zhao, M.; Wang, J.; Yang, B.; Jiang, Y. Antioxidant activity of methanolic extract of emblica fruit (Phyllanthus emblica L) from six regions in China. J. Food Compos. Anal. 2008, 21, 219-228. [CrossRef]

43. Tung, Y.T.; Cheng, K.C.; Ho, S.T.; Chen, Y.L.; Wu, T.L.; Hung, K.C.; Wu, J.H. Comparison and characterization of the antioxidant potential of 3 wild grapes-Vitis thunbergii, V. flexuosa, and V. kelungeusis. J. Food Sci. 2011, 76, 701-706. [CrossRef] [PubMed]

44. George, B.P.; Parimelazhagan, T.; Chandran, R. Anti-inflammatory and wound healing properties of Rubus fairholmianus Gard. Root-An in vivo study. Ind. Crops Prod. 2014, 54, 216-225. [CrossRef]

45. Skorić, M.; Gligorijević, N.; Cavić, M.; Todorović, S.; Janković, R.; Ristić, M.; Misić, D.; Radulović, S. Cytotoxic activity of Nepeta rtanjensis Diklić \& Milojević essential oil and its mode of action. Ind. Crops Prod. 2017, 100, 163-170.

46. Grbić, M.L.; Stupar, M.; Vukojević, J.; Soković, M.; Mišić, D.; Grubišić, D.; Ristić, M. Antifungal activity of Nepeta rtanjensis essential oil. J. Serb. Chem. Soc. 2008, 73, 961-965. [CrossRef]

47. Kumar, V.; Mathela, C.S.; Tewari, G.; Singh, D. Antifungal activity of Nepeta elliptica Royle ex Benth. oil and its major constituent (7R)-trans, trans-nepetalactone: A comparative study. Ind. Crops Prod. 2014, 55, 70-74. [CrossRef]

48. Morcia, C.; Malnati, M.; Terzi, V. In vitro antifungal activity of terpinen-4-ol, eugenol, carvone, 1,8-cineole (eucalyptol) and thymol against mycotoxigenic plant pathogens. Food Addit. Contam. A. 2012, 29, 415-422.

49. Taskina, A.; Javan, M.; Sonboli, A.; Semnanian, S. Evaluation of the antinociceptive and anti-inflammatory effects of essential oil of Nepeta pogonosperma Jamzad et Assadi in rats. DARU J. Pharm. Sci. 2012, $20,48$.

50. Sharifi-Rad, J.; Hoseini-Alfatemi, S.M.; Miri, A.; Sharifi-Rad, M.; Soufi, L.; Sharifi-Rad, M.; Setzer, W.N.; Hoseini, M.; Sharifi-Rad, M.; Rokni, M. Phytochemical analysis, antioxidant and antibacterial activities of various extracts from leaves and stems of Chrozaphora tinctoria. Environ. Exp. Biol. 2015, 13, 169-175. 
51. Dewanto, X.; Wu, K.; Adom, K.; Liu, R.H. Thermal processing enhances the nutritional value of tomatoes by increasing total antioxidant activity. J. Agric. Food Chem. 2002, 50, 3010-3014. [CrossRef]

52. Chang, C.C.; Yang, M.H.; Wen, H.M.; Chern, J.C. Estimation of total flavonoid content in propolis by two complementary colorimetric methods. J. Food Drug Analysis. 2002, 10, 178-182.

53. Vega-arroy, D.J.; Ruíz-espinosa, H.; Luna-guevara, J.J.; Luna-guevara, M.L.; Hernández-carranza, P.; Ávila-sosa, R.; Ochoa-velasco, C.E. Effect of solvents and extraction methods on total anthocyanins, phenolic compounds and antioxidant capacity of Renealmia alpinia (Rottb.) Maas peel. Czech J. Food Sci. 2017, 35, 456-465. [CrossRef]

54. Sun, B.; Richardo-Da-Silvia, J.M.; Spranger, I. Critical factors of vanillin assay for catechins and proanthocyanidins. J. Agric. Food Chem. 1998, 46, 4267-4274. [CrossRef]

55. Adams, R.P. Identification of Essential Oil Components by Gas Chromatography/Mass Spectrometry; Allured Publishing Corporation: Carol Stream, IL, USA, 1995.

56. Sharifi-Rad, J.; Hoseini-Alfatemi, S.M.; Sharifi-Rad, M.; da Silva, J.A.T. Antibacterial, antioxidant, antifungal and anti-inflammatory activities of crude extract from Nitraria schoberi fruits. 3Biotech. 2015, 5, 677-684. [CrossRef] [PubMed]

57. Benzie, I.F.; Strain, J.J. The ferric reducing ability of plasma (FRAP) as a measure of "antioxidant power": The FRAP assay. Anal. Biochem. 1996, 239, 70-76. [CrossRef]

58. Saotome, K.; Morita, H.; Umeda, M. Cytotoxicity test with simplified crystal violet staining method using microtiter plates and its application to injection drugs. Toxicol. In Vitro 1989, 3, 317-321. [CrossRef]

59. Quan, H.; Cao, Y.Y.; Xu, Z.; Zhao, J.X.; Gao, P.H.; Qin, X.F.; Jiang, Y.Y. Potent in vitro synergism of fluconazole and berberine chloride against clinical isolates of Candida albicans resistant to fluconazole, Antimicrob. Agents Chemother. 2006, 50, 1096-1099. [CrossRef]

60. Sharifi-Rad, M.; Iriti, M.; Sharifi-Rad, M.; Gibbons, S.; Sharifi-Rad, J. Anti-methicillin-resistant Staphylococcus aureus (MRSA) activity of Rubiaceae, Fabaceae and Poaceae plants: A search for new sources of useful alternative antibacterials against MRSA infections. Cell. Mol. Biol. 2016, 62, 39-45.

61. Clinical and Laboratory Standards Institute (CLSI). Reference Method for Dilution Antimicrobial Susceptibility Tests for Bacteria that Grow Aerobically; Approved standard M7-A6, National Committee for Clinical Laboratory Standards: Wayne, PE, USA, 2012.

(C) 2020 by the authors. Licensee MDPI, Basel, Switzerland. This article is an open access article distributed under the terms and conditions of the Creative Commons Attribution (CC BY) license (http://creativecommons.org/licenses/by/4.0/). 